\title{
CITY MAGISTRATE OF TSARITSYN AS THE ESTATES COURT FOR URBAN POPULATION. 1784-1866
}

\author{
Elena V. Bulyulina \\ Volgograd State University, Volgograd, Russian Federation \\ Valentina V. Melnikova \\ State Archive of the Volgograd Region, Volgograd, Russian Federation
}

\begin{abstract}
At the end of the $18^{\text {th }}$ century in Russia caste system of the judiciary was legalized. For urban and suburban trade and craft population of the Russian Empire estates courts were magistrates. Despite the fact that the activities of magistrates are studied by native historians and legal scholars, regional aspects of the topic are not adequately reflected. This article examines the activities of the Tsaritsyn city magistrate court as an estates court for a merchant and petty-bourgeois population of the city of Tsaritsyn in 1784-1866.

In 1775 Ekaterina II carried out a major reform of local government and the court, significantly expanding the functions of local government institutions, and, in fact, restoring estates of municipal government. From that moment in cities the magistrates managed the city, including city magistrates who represented the court of first instance in criminal and civil cases for the urban population - merchants, craftsmen, townspeople. Appeal to the city magistrate was of the Saratov provincial magistrate. Different aspects of his functional features and relations with another official instances are presented.

The limits of the jurisdiction of the Tsaritsyn city magistrate was limited to the territory of Tsaritsyn. The objects of the jurisdiction could be only the regular citizens, i.e. assigned to the city, and not the entire population. Implementation of the rule of law, particularly the application of penalties in the material presented in the aspect of not only the all-Russian legal requirements, but also regarding regional social and legal assessments.

Tsaritsyn city magistrate heard cases of theft, vandalism, rape, false receipts, and bills of exchange, unauthorized occupation of urban land, abandoned children, the accountability for deviations from the canons of Orthodoxy, committing a schismatic rites, violation of rules of transportation and logging, concealment of recruits, about the insult of the authorities. Here is the study of practice associated with the historical, social, religious, cultural and ethnic features of the region. The focus of attention is fixed on the functionality of local institutions in a changing social and legal environments taking place in the country and its regions.

The main stage of the proceedings the magistrate stationery was records management. The trial differed extensive paperwork, lots revisewise and appellate courts, exclusion of the parties from the process. These characteristics, constraints and delay the proceedings, led to the reform of the judicial system in the mid-nineteenth century.
\end{abstract}

Key words: city magistrates, estates courts, court proceedings, merchants, city management, Tsaritsyn.

Citation. Bulyulina E.V., Melnikova V.V. City Magistrate of Tsaritsyn as the Estates Court for Urban Population. 1784-1866. Vestnik Volgogradskogo gosudarstvennogo universiteta. Serija 4, Istorija. Regionovedenie. Mezhdunarodnye otnoshenija [Science Journal of Volgograd State University. History. Area Studies. International Relations], 2017, vol. 22, no. 4, pp. 130-138. (in Russian). DOI: https://doi.org/10.15688/jvolsu4.2017.4.12

\section{ЦАРИЦЫНСКИЙ ГОРОДОВОЙ МАГИСТРАТ КАК СОСЛОВНЫЙ СУД ГОРОДСКОГО НАСЕЛЕНИЯ. 1784-1866 ГГ.}

\author{
Елена Владимировна Булюлина
}

Волгоградский государственный университет, г. Волгоград, Российская Федерация 


\section{Валентина Владимировна Мельникова}

Государственный архив Волгоградской области, г. Волгоград, Российская Федерация

Аннотация. В конце XVIII в. в России была законодательно оформлена система сословных судебных органов. Для городского и посадского торгово-ремесленного населения Российской империи сословными судами являлись магистраты. Несмотря на то, что деятельность магистратов достаточно подробно изучена отечественными историками и правоведами, региональные аспекты темы недостаточно отражены. В предлагаемой статье рассматривается деятельность Царицынского городового магистрата как сословного суда для купеческого и мещанского населения г. Царицына в 1784-1866 годах.

В 1775 г. Екатерина II провела большую реформу местного управления и суда, значительно расширив функции местных государственных учреждений и фактически восстановив органы сословного городского самоуправления. Отныне в городах в ведении магистратов находилось все управление городом, в том числе городовые магистраты являлись сословным судом первой инстанции по уголовным и гражданским делам для городского населения - купцов, ремесленников, мещан. Апелляционной инстанцией для городового магистрата был Саратовский губернский магистрат.

Пределы подсудности Царицынского городового магистрата ограничивались территорией Царицына. Объектами подсудности могли выступать лишь граждане регулярные, то есть приписанные к городу, а не все население.

Царицынский городовой магистрат рассматривал дела о кражах, хулиганстве, изнасиловании, подложных расписках и векселях, самовольном захвате городской земли, подкинутых детях, привлечении к ответственности за отступления от канонов православия, совершении раскольничьих обрядов, нарушении правил перевозки и рубки леса, укрывательстве рекрутов, об оскорблении начальства.

Главным этапом судопроизводства магистрата было канцелярское оформление дела. Судебный процесс отличался обширным бумажным делопроизводством, множеством ревизующих и апелляционных инстанций, отстраненностью сторон от процесса. Эти характерные черты, затруднявшие и затягивающие судопроизводство, привели к реформированию судебной системы в середине XIX века.

Проблемы, которые поднимаются в статье, изучены авторами (В.В. Мельниковой и Е.В. Булюлиной) совместно: в равной степени осуществлена работа по выявлению и анализу литературы и исторических источников. Е.В. Булюлиной проведен анализ результатов исследования, подготовлен текст статьи к публикации.

Ключевые слова: городовые магистраты, сословные суды, судопроизводство, купечество, городское управление, Царицын.

Цитирование. Булюлина Е. В., Мельникова В. В. Царицынский городовой магистрат как сословный суд городского населения. 1784-1866 гг. // Вестник Волгоградского государственного университета. Серия 4, История. Регионоведение. Международные отношения. - 2017. - Т. 22, № 4. - С. 130-138. - DOI: https:// doi.org/10.15688/jvolsu4.2017.4.12

Судебная система занимает особое место среди органов управления, составляющих единый государственный механизм. Она представляет собой совокупность судов, осуществляющих свои функции на территории всего государства в рамках действующего законодательства, и является одним из важнейших политических институтов. Принципы деятельности и структура судебных учреждений формируются под влиянием тенденций, возникающих в обществе на определенном этапе его исторического развития. В связи с этим изучение эволюции судебной системы в целом и отдельных судебных учреждений позволяет проанализировать содержание исторического процесса.

В конце XVIII в. была законодательно оформлена система сословных судебных ор- ганов. Для городского и посадского торговоремесленного населения Российской империи сословными судами являлись магистраты.

Деятельности магистратов посвящена обширная научная литература. Авторы многочисленных работ изучают образование и функционирование этих органов в контексте проблем истории государственного управления $[1 ; 3 ; 15 ; 16 ; 18 ; 33 ; 35]$, права $[4 ; 11 ; 17$; $19 ; 30]$, истории судебных учреждений (что касается последнего аспекта, то историография проблемы столь велика, что ИНИОН подготовил специальный сборник обзоров, ее анализирующих [12]). Исчерпывающие историографические обзоры по теме магистратов содержатся в недавно защищенных диссертациях $[17 ; 22 ; 29 ; 31]$. 
Исключительный интерес представляет изучение этой темы на примере российской провинции, отличающейся разнообразием географических, культурно-этнических, социально-экономических, административных и других особенностей. Однако подобных работ, касающихся отдельных регионов России, не так уж много, если учитывать обширную территорию нашего отечества [2; $5 ; 7 ; 9 ; 14 ; 36]$. Если говорить о Царицыне, то наибольшей информативностью отличается статья Т.А. Солоповой «Магистраты Саратовской губернии» [32] и кандидатская диссертация С.А. Преферансова, касающаяся лингвистических параметров делопроизводственной документации Царицынского магистрата [22]. Имеются также публикации авторов этой статьи $[3 ; 20]$.

Цель данного исследования - изучение деятельности Царицынского городового магистрата как сословного суда для купеческого и мещанского населения г. Царицына.

В работе были применены системный, структурно-функциональный, архивно-эвристический, источниковедческий методы, метод исторического описания и актуализации.

Работа основана на неопубликованных архивных документах фонда Царицынского городового магистрата, хранящегося в Государственном архиве Волгоградской области (ГАВО). В фонде 778 единиц хранения за 1784 1870 годы. Эти документы поступили в ГАВО в 1951 г. из Государственного архива Саратовской области (ГАСО) в количестве 555 ед. хр. за 1800-1870 гг., а также в июне 1965 г. из Российского государственного архива древних актов (РГАДА) в количестве 130 ед. хр. за 17841799 годы. В фонде имеются указы Саратовского губернского и наместнического правлений, протоколы заседаний и решения магистрата, акты ревизий доходов и расходов магистрата, журналы заседаний магистрата, книги записи актов об освобождении крестьян от крепостной зависимости, книги купчих и закладных на недвижимое имущество, торговых контрактов, свидетельств, векселей, переписка с Саратовским губернским правлением, Царицынским сиротским, земским судами, полицейским управлением и другими учреждениями. Документы содержат многоаспектную информацию, отражающую не только деятельность Царицын- ского городового магистрата как судебно-административного органа, но и вопросы жизнедеятельности населения Царицына конца XVIII - второй половины XIX в., в связи с этим они представляют ценность как исторический источник.

Со времени образования Царицына в 1589 г. и до начала XVIII в. главным звеном местного управления являлся воевода, он же отправлял и судебные функции. Городовые магистраты в Российской империи были учреждены на основании Регламента Главного магистрата от 16 января 1721 г. как административно-судебные органы городского населения [21, т. 6, ст. 3708]. Таким образом, судопроизводство велось и городовым магистратом, и воеводской канцелярией.

В 1727 г. магистраты были подчинены губернаторам и воеводам [21, т. 7 , ст. 5142$]$, в 1728 г. - заменены ратушами [21, т. 8, ст. 53020], в 1743 г. - восстановлены. В ведении восстановленных магистратов остались главным образом финансовые дела: сбор податей, кабацкая, соляная и таможенная службы. Судебные решения магистрата можно было обжаловать у воеводы. Воевода и возглавляемая им канцелярия поглотили почти все функции местного государственного аппарата.

В 1775 г. Екатерина II провела большую реформу местного управления и суда, значительно расширив функции местных государственных учреждений и фактически восстановив органы сословного городского самоуправления. Отныне в городах в ведении магистратов находилось все управление городом, в том числе городовые магистраты являлись сословным судом первой инстанции по уголовным и гражданским делам для городского населения - купцов, ремесленников, мещан. Одновременно в уездах Российской империи появились сословные суды первой инстанции и для других сословий: уездный суд - для дворян и нижняя земская расправа - для непомещичьих крестьян. Апелляционной инстанцией для городового магистрата был губернский магистрат.

Городовые магистраты действовали в соответствии с Инструкцией магистратам 1724 г., а позднее - «Грамотой на права и выгоды городам Российской империи» от 24 апреля 1785 года. Как коллегиальный орган, ма- 
гистраты состояли из президента (в 1744 г. должность ликвидирована), 2-4 бурмистров и 2-8 ратманов. Должности были выборные из местного городского общества. Кандидатов выдвигало общество, список подавал городской голова в магистрат, затем кандидатуры утверждались губернским правлением.

После проведения реформы Царицынский городовой магистрат был вновь учрежден 12 марта 1784 года.

В журнале Царицынской воеводской канцелярии от 11 марта 1784 г. записано: «п. 10. Слушали: Предложение Саратовской Верхней расправы от председателя, что 12 числа нынешнего месяца имеет последовать в городе Царицыне открытие уже новых присутственных мест Нижней расправы, Нижнего земского суда и городового магистрата токмо с того числа и заседание уже назначается. Приказал оное предложение приложить к прочим таковым... а сверх того это оным предложено исполнять немедленно» [23, л. 16]. При городовом магистрате был учрежден сиротский суд сословный орган купеческой опеки [7].

Первое заседание вновь созданного Царицынского городового магистрата состоялось 15 марта 1784 года. Бургомистрами состояли: Мышин Григорий и Сафонов Степан, ратманами: Солодников Илья, Бабаев Алексей, Татаркин Алексей, Никульченков Александр [24, л. 1]. Бургомистры и ратманы магистрата избирались на три года из купцов IІІ гильдии.

По Регламенту Главного магистрата горожане подразделялись на регулярных и нерегулярных («подлых»). Регулярные делились на гильдии и цехи. Вначале гильдии делились по профессиональному признаку. Затем гильдии превратились в купеческие объединения по состоянию имущества. Запись в цехи была обязательной для всех ремесленников. Гильдии и цехи подчинялись магистрату, имели своих старшин, которые занимались как сословными делами, так и государственным управлением в области полиции и финансовых сборов (учет тяглового населения, взимание подушной подати, рекрутские наборы и др.) [10, с. 101-102].

Окончательно права гильдейского купечества были оформлены Жалованной грамотой городам 1785 года.
С 1785 г. бургомистры и ратманы избирались только из купцов I и II гильдий. В общей думе и шестигласной думе (исполнительном органе городского самоуправления) купечество имело представительство от каждой гильдии.

С 1824 г. только купцы I гильдии могли быть городскими головами, заседателями палат, совестных судов; купцы ІІ гильдии могли занимать должности бургомистров, ратманов, членов судоходных расправ (рассматривали споры судовладельцев); купцы III гильдии - должности городских старост, членов шестигласных дум, депутатов в разных учреждениях.

Аппарат магистрата состоял из присутствия - 2-3 бургомистров и 4 ратманов. Также имелись канцелярские служащие:

- секретарь;

- столоначальник;

- архивариус;

- журналист (регистрировал входящие и исходящие документы);

- писец первого разряда;

- писец второго разряда;

- два канцеляриста;

- четыре копииста.

Деятельность аппарата магистрата была регламентирована: начинались заседания в 8 часов утра, заканчивались в 2 часа дня. Были и «секретные» заседания. На них присутствовали представители дворянства и судов. На протоколах делалась отметка «По секрету».

Заседания не проводились по субботам (кроме 1809, 1820 гг.) и воскресеньям, в дни религиозных праздников и дни рождения членов царствующей семьи.

Судопроизводство городового магистрата велось аналогично судопроизводству уездного суда. Следствие проводилось органами городской полиции. Затем материалы дела поступали в канцелярию магистрата, где секретарь и его помощники на основании этих материалов составляли подробную записку с содержанием дела, доводами сторон, справками и ссылками на законы. После составления такой записки стороны и их доверенные удостоверяли правильность фактов своими подписями. Секретарь докладывал краткое изложение дела общему присутствию, заседавшему в особой комнате. Доступ сторон в 
эту комнату запрещался. За время заседания рассматривалось несколько дел.

Решение Царицынского городового магистрата могло быть обжаловано в Саратовском губернском магистрате, а также в общесословных судах - Саратовской губернской палате уголовного суда и Саратовской губернской палате гражданского суда, далее в Сенате. Была разработана система подачи апелляций. Устанавливался недельный срок по объявлении приговора для заявления о ее подаче. Пересмотр в апелляционном порядке допускался лишь в отношении гражданских и тех уголовных дел, которые возбуждались по инициативе пострадавших. Прочие уголовные дела могли пересматриваться только по инициативе суда высшей инстанции.

Дела могли передаваться на «ревизию» в то или иное административное учреждение. В таком случае дело дополнялось новыми документами, собранными с помощью полиции.

Пределы подсудности городового магистрата ограничивались территорией Царицына. Объектами подсудности могли выступать лишь граждане регулярные, то есть приписанные к городу, а не все население.

Царицынский городовой магистрат рассматривал дела о кражах, хулиганстве, изнасиловании, подложных расписках и векселях, самовольном захвате городской земли, подкинутых детях, привлечении к ответственности за отступления от канонов православия, совершении раскольничьих обрядов, нарушении правил перевозки и рубки леса, укрывательстве рекрутов, об оскорблении начальства.

Так, царицынский купец Василий Воронин был строго наказан за захват городской земли на реке Царица под строительство шерстомойни. Воронин доказывал, что еще 15 лет назад получил разрешение на землю у городского головы. Рассмотрение дела длилось несколько лет: с 1850 по 1858 год. 22 августа 1858 г. было решено: «Взыскать с Воронина Василия денег за время пользования землей, городу принадлежащей... принять все законные меры к возвращению городской собственности...» [34, л. 28-28 об.].

10 марта 1859 г. слушали отношение царицынской градской полиции о захвате дворового места друг у друга купеческих детей Татаркиных Петра и Андрея Ивановых; Бердни- кова Михаила Дмитриева и вдовы унтер-офицерской Плечистовой Екатерины Ивановой; 4 сентября 1863 г. - части дворового места у отставного казака Астраханского казачьего войска Купнова Ильи Степанова купцом Дибвиным Степаном Григорьевым [28, л. 7].

Городовой магистрат 26 марта 1846 г. рассмотрел, например, прошение царицынского купца Шешминцова Андрея о должнике Дмитрии Лапшине, царицынском мещанине, в сумме 404 руб. 4 коп. серебром. Решение магистрата: «...обязать подпискою о невыезде его, Лапшина, из города Царицына» [25, л. 38].

Магистрат разбирал конфликты обывателей. Так, 18 декабря 1858 г. на царицынском базаре царицынская мещанка Курынскова Марья «жестоко обидела» Двоскина Николая Григорьева, царицынского мещанина, - ударила по лицу «и вырвала из бороды его клок волос», и он подал прошение в магистрат [27, л. 207].

Подал прошение 26 мая 1858 г. в магистрат и царицынский мещанин Бугровский Петр Евдокимов, владелец торгового балагана за p. Царицей. Его племянник Лапшин Василий Петров «между разговорами, прийдя в азарт, выбегал на дорогу и во все горло кричал, что он, Бугровский, вор, что он поворовал у крестьянина Треумова брусья и еще у кого-то две бочки смолы, тому были свидетели царицынские мещане: Тихон Фролов, Федор Сидоров, Александр и Михаил Зверевы и др.» [26, л. 57-57 об.].

Документы магистрата оформлялись на бумаге с водяными знаками и гербовой бумаге российских фабрик.

Протоколы имели определенную форму: в левом верхнем углу указывался номер документа, дата (год, месяц, число, день недели). Далее отмечалось: «В присутствии Царицынского городового магистрата прибыли: бургомистры (Ф.И.), ратманы (Ф.И.)».

Указывалось время начала заседания: «Пополуночи в 8-м часу».

Слушали: № вопроса, его суть.

В конце вопроса следовало: «Приказали».

Заканчивались заседания в 2 часа пополудни.

В правой стороне документа шло графление:

\begin{tabular}{|l|l|}
\hline $\begin{array}{l}\text { Когда протокол } \\
\text { скреплен }\end{array}$ & $\begin{array}{l}\text { Когда исполнение } \\
\text { учинено }\end{array}$ \\
\hline
\end{tabular}


Протокол оформлял секретарь, бургомистры и ратманы ставили свои подписи (некоторые использовали факсимиле, например, Ф. Быстров, В. Хабаров); в некоторых делах имеются внутренние описи, алфавитные реестры; книги регистрации векселей и писем прошнурованы, поставлены сургучные печати.

Городовые магистраты были упразднены именным указом «Правила об упразднении магистратов и ратуш» от 13 апреля 1866 года. Их функции переданы городской думе, казенной палате, уездному казначейству и полицейскому управлению. Судебные функции были переданы новым судебным учреждениям - мировым судьям, избиравшимся на три года местными органами городского самоуправления, и окружным судам, создававшимся на несколько уездов.

Таким образом, Царицынский городовой магистрат с конца XVIII до середины XIX в. представлял собой административно-судебный орган городского управления. Наряду с административными функциями, он играл роль сословного суда первой инстанции для купеческого и мещанского населения Царицына. Решающим этапом судопроизводства было канцелярское оформление дела. Гражданский процесс отличался от уголовного лишь по форме. Обширное бумажное делопроизводство, множество ревизующих и апелляционных инстанций, отстраненность сторон от процесса, отсутствие адвокатуры, запутанность самого процесса были характерными чертами дореформенной судебной системы. К середине XIX в. судебная система России вызывала недовольство всех слоев населения, что и послужило причиной утверждения новых судебных уставов 1864 г., вводивших в Российской империи буржуазные принципы судоустройства и судопроизводства.

\section{СПИСОК ЛИТЕРАТУРЫ}

1. Анисимов, Е. В. Реформы Екатерины II / Е. В. Анисимов // Власть и общество: от самодержавной к советской России. - СПб., 1996. -С. 164-190.

2. Астраханбиева, О. А. Деятельность Печерского городового магистрата в конце XVIII века / О. А. Астраханбиева // Шестые Псковские региональные краеведческие чтения. - Псков, 2016. C. $183-188$.
3. Булюлина, Е. В. Из истории судебных учреждений Царицына-Сталинграда, 1589-1928 годы / Е. В. Булюлина // Вестник Волгоградского государственного университета. Серия 4, История. Регионоведение. Международные отношения. 2008. -№ 1 (13). - C. 20-26.

4. Владимирский-Буданов, М. Ф. Обзор истории русского права / М. Ф. Владимирский-Буданов. - Ростов н/Д : Феникс, 1995. - 640 с.

5. Воропанов, В. А. Первые судебные учреждения города / В. А. Воропанов // Вестник Челябинского университета. Серия 1, История. - 2000. № 1. - C. 79-85.

6. Государственный архив Волгоградской области (далее - ГАВО). - Ф. 162. - Дело фонда.

7. Демина, Т. А. Источники формирования городских сословий на Урале во второй половине XVIII в. / Т. А. Демина, А. С. Черкасов // Деревня и город Урала в эпоху феодализма: проблемы взаимодействия. - Свердловск, 1986. - С. 53-65.

8. Демкин, А. В. Русское купечество XVIIXVIII вв.: города Верхневолжья / А. В. Демкин. М. : Наука, 1990. $-94 \mathrm{c}$.

9. Евдокимова, С. В. Некоторые вопросы управления городов Забайкалья в конце XVIII - первой половине XIX в. / С. В. Евдокимова // Политика Царизма в Сибири в XIX - начале XX в. - Иркутск, 1987. - C. 34-50.

10. Ерошкин, Н. П. История государственных учреждений дореволюционной России / Н. П. Ерошкин. - М. : РГГУ, 2008. - 710 с.

11. Ефремова, Е. Н. Судебно-следственные дела как источник изучения купечества / Е. Н. Ефремова // Исследования по источниковедению истории России (до 1917 г.) : сб. ст. - М. : ИРИ РАН, 2003. - C. 178-193.

12. История судебных учреждений России : сб. обзоров и реф. - М. : ИНИОН РАН, 2004. -220 с.

13. Каменский, А. Б. Сословная политика Екатерины II / А. Б. Каменский // Вопросы истории. 1995. - № 3. - C. 29-45.

14. Каменский, А. Б. Повседневная жизнь русского города XVIII века : по материалам Бежецкого городового магистрата / А. Б. Каменский // Управление городами: история и современность : материалы науч. конф., 23- 24 нояб. 2000 г. - Тверь : [б. и.], 2001.-С. 142-154.

15. Козлова, Н. В. Городское самоуправление и городская администрация в России XVIII века / Н. В. Козлова // Управление городами: история и современность : материалы науч. конф., 23-24 нояб. 2000 г. - Тверь : [б. и.], 2001. - С. 100-108.

16. Козлова, Н. В. Российский абсолютизм и купечество в XVIII веке (20-е - начало 60-х годов) / Н. В. Козлова. - М. : Археографическимй центр, 1999. $-381 \mathrm{c}$. 
17. Лавринович, М. Б. Реформаторская политика Екатерины II в области городового законодательства (1762-1796) : дис. ... канд. ист. наук / Лавринович Майя Борисовна ; РГГУ. - М., 2001. - 295 с.

18. Марасанова, В. В. Перестройка органов власти и управления в конце XVIII в. / В. В. Марасанова // Государственное управление: история и современность : материалы Междунар. науч. конф., г. Москва, 29-30 мая 1997 г. / МГУ им. Ломоносова. - М., 1998. - С. 104-106.

19. Мельгунова, Т. П. Право, администрация и суд в реформах Екатерины Великой / Т. П. Мельгунова. СПб. : Изд-во РГПУ им. А. И. Герцена, 2002. -412 с.

20. Мельникова, В.В.Царицынский городовой магистрат в конце XVIII - XIX в. / В. В. Мельникова. - Волгоград : Волгогр. науч. изд-во, 2017. - 79 с.

21. Полное собрание законов Российской империи (ПСЗ РИ). - Собр. 1. - Спб., 1830.

22. Преферансов, С. А. Отражение общерусских норм и местных особенностей составления документов в делопроизводстве Царицынского городового магистрата : на материале источников конца XVIII века : дис. ... канд. филол. наук / Преферансов Сергей Александрович. - Волгоград, 2012. - 167 с.

23. Протокол воеводской канцелярии от 11 марта 1784 года // ГАВО. - Ф. 331. - Оп. 1. - Д. 34.

24. Протокол заседания Царицынского городового магистрата от 15 марта 1784 года // ГАВО. Ф. 233. - Оп. 2. - Д. 1.

25. Протокол заседания Царицынского городового магистрата от 26 марта 1846 года // ГАВО. Ф. 233. - Оп. 1. - Д. 158.

26. Протокол заседания Царицынского городового магистрата от 26 мая 1858 года // ГАВО. Ф. 233. - Оп. 1. - Д. 347.

27. Протокол заседания Царицынского городового магистрата от 18 декабря 1858 года // ГАВО. Ф.233. - Оп.1. - Д.348.

28. Протокол заседания Царицынского городового магистрата от 4 сентября 1858 года // ГАВО. Ф. 233. - Оп. 1. - Д. 445.

29. Савельев, В. В. Градостроительная реформа Екатерины II: формирование приемов «регулярного» градостроительства и механизм их осуществления (по материалам Тверского наместничества) : автореф. дис. ... канд. искусствоведения / Савельев Вячеслав Вадимович. -СПб., 2002. - 274 с.

30. Середа, Н. В. Городовые магистраты в российском законодательстве XVIII века / Н. В. Середа // Из архива тверских историков. - Тверь, 2002. C. 24-59.

31. Середа, Н. В. Городовые магистраты последней четверти XVIII в. : источниковедческое исследование по материалам Тверской губернии : дис. ... канд. ист. наук / Середа Надежда Владимировна ; РГГУ. - М., 1994. - 278 с.
32. Солопова, Т. А. Магистраты Саратовской губернии / Т. А. Солопова // Историк и историография. -Саратов : Изд-во Сарат ун-та, 1999. - С. 178-187.

33. Тарловская, В. Р. Из истории городской реформы в России конца XVII - начала XVIII в. / В. Р. Тарловская // Государственные учреждения России XVI-XVIII вв. - М., 1991. - C. 98-118.

34. Указ Саратовского губернского правления от 22 августа 1858 года // ГАВО. - Ф. 233. - Оп. 1. Д. 234.

35. Уткин, Д. Е. Реформа местного управления Екатерины II: опыт децентрализации исполнительной власти / Д. Е. Уткин // Вестник Ярославского государственного университета им. П. Г. Демидова. Серия «Гуманитарные науки». - 2016. № 2 (36). - С. 15-18.

36. Хохолев, Д. Е. Екатеринбургский городовой магистрат в системе управления Пермского наместничества (1781-1796 гг.) / Д. Е. Хохолев // Проблемы истории местного управления Сибири конца XVI-XX веков : материалы 4-й региональной науч. конф, 11-12 нояб. 1999 г. - Новосибирск : [б. и.], 1999. - C. 194-199.

\section{REFERENCES}

1. Anisimov E.V. Reformy Ekateriny II [Catherine II's Reforms]. Vlast i obshchestvo: ot samoderzhavnoy ksovetskoy Rossii [Power and Society: from Autocratic to Soviet Russia]. Saint Petersburg, 1996, pp. 164-190.

2. Astrakhanbieva O.A. Deyatelnost Pecherskogo gorodovogo magistrata v kontse XVIII veka [Activities of the Pechersk City Magistrate at the End of the $18^{\text {th }}$ century]. Shestye Pskovskie regionalnye kraevedcheskie chteniya [Sixth Pskov Regional Local History Readings]. Pskov, 2016, pp. 183-188.

3. Bulyulina E.V. Iz istorii sudebnykh uchrezhdeniy Tsaritsyina-Stalingrada. 1589-1928 gody [From the History of Judicial Institutions of TsaritsynStalingrad. 1589-1928]. Vestnik Volgogradskogo gosudarstvennogo universiteta. Seriya 4, Istoriya. Regionovedenie. Mezhdunarodnye otnosheniya [Science Journal of Volgograd State University. History. Area Studies. International Relations], 2008, no. 1 (13), pp. 20-26.

4. Vladimirskiy-Budanov M.F. Obzor istorii russkogo prava [Review of the History of Russian Law]. Rostov-on-Don, Phoenix Publ., 1995. 640 p.

5. Voropanov V.A. Pervye sudebnyye uchrezhdeniya goroda [The First Judicial Institutions of the City]. Bulletin of the University of Chelyabinsk. Ser. 1. History, 2000, no. 1, pp. 79-85.

6. Gosudarstvennyy arkhiv Volgogradskoy oblasti [State Archive of the Volgograd Region], F. 162 (fond case). 
7. Demina T.A. Istochniki formirovaniya gorodskikh sosloviy na Urale vo vtoroy polovine XVIII v. [Sources of Urban Estates in the Urals in the Second Half of the $18^{\text {th }}$ Century]. Derevnya $i$ gorod Urala v epokhu feodalizma: problemy vzaimodeystviya [The Village and the City of the Urals in the Era of Feudalism: the Problem of Interaction]. Sverdlovsk, 1986, pp. 53-65.

8. Demkin A.V. Russkoe kupechestvo XVII-XVIII vv: goroda Verkhnevolzhya [Russian Merchants in the $17^{\text {th }}-18^{\text {th }}$ Centuries: Cities of Upper Volga Region]. Moscow, Nauka Publ., 1990. 94 p.

9. Evdokimova S.V. Nekotoryye voprosy upravleniya gorodov Zabaykalya v kontse XVIII pervoy polovine XIX v. [Some Issues of Urban Management of Trans-Baikal Cities in the Late $18^{\text {th }}$ First Half of the $19^{\text {th }}$ Centuries]. Politika tsarizma $v$ Sibiri $v X I X-$ nachale $X X v$. [Tsarist Policy in Siberia in the $19^{\text {th }}-20^{\text {th }}$ Centuries]. Irkutsk, 1987, pp. 34-50.

10. Eroshkin N.P. Istoriya gosudarstvennykh uchrezhdeniy dorevolyutsionnoy Rossii [The History of Public Institutions of Pre-Revolutionary Russia]. Moscow, Russian State Humanitarian University, 2008. $710 \mathrm{p}$.

11. Efremova E.N. Sudebno-sledstvennyye dela kak istochnik izucheniya kupechestva [Forensic Investigation Files as a Source of Study of the Merchants]. Issledovaniya po istochnikovedeniyu istorii Rossii (do 1917 g.): sb. statey / Institut rossiyskoy istorii RAN [Research on Source Studies of Russian History (up to 1917): Collected Articles / Institute of Russian History, RAS]. Moscow, 2003, pp. 178-193.

12. Istoriya sudebnykh uchrezhdeniy Rossii: sb. obzorov $i$ ref. [The History of Russian Judicial Institutions: Collected Reviews and References]. Moscow, INION Publ., 2004. 220 p.

13. Kamenskiy A.B. Soslovnaya politika Ekateriny II [The Class Policy of Catherine II]. Voprosy istorii [Questions of history], 1995, no. 3, pp. 29-45.

14. Kamenskiy A.B. Povsednevnaya zhizn russkogo goroda XVIII veka: po materialam Bezhetskogo gorodovogo magistrata [Everyday Life of Russian City of the $18^{\text {th }}$ Century: Materials of Bezhetsk City Magistrate]. Upravleniye gorodami: istoriya i sovremennost: Materialy nauch. konf. 2324 noyab. 2000 g. [Urban Governance: History and Modernity. Materials of Scientific Conference, November 23-24, 2000]. Vologda, 2001, pp. 142-154.

15. Kozlova N.V. Gorodskoe samoupravlenie i gorodskaya administratsiya v Rossii XVIII veka [Municipal Self-Government and the City Administration of the $18^{\text {th }}$ Century in Russia]. Upravlenie gorodami: istoriya i sovremennost [Urban Governance: History and Modernity]. Tver, 2001, pp.100-108.
16. Kozlova N.V. Rossiyskiy absolyutizm $i$ kupechestvo v XVIII veke (20-e - nachalo 60-kh godov) [Russian Absolutism and the Merchants in the $18^{\text {th }}$ Century (1920s - early 1960s)]. Moscow, Archeographic Center, 1999, 381 p.

17. Lavrinovich M.B. Reformatorskaya politika Ekateriny II v oblasti gorodovogo zakonodatelstva (1762-1796) [Reformation Policy of Catherine II in the City Legislation (1762-1796)]. Moscow, 2001, 295 p.

18. Marasanova V.V. Perestroyka organov vlasti i upravleniya $\mathrm{v}$ kontse XVIII v. [Reorganization of Governing Bodies at the End of the $18^{\text {th }}$ Century]. Gosudarstvennoe upravlenie: istoriya $i$ sovremennost: materialy mezhdunarodnoy nauchnoy konferentsii. Moskva, 29-30 maya 1997 g. [Public Administration: Past and Present: Proceedings of the International Conference. Moscow, May 29-30, 1997]. Moscow, 1998, pp. 104-106.

19. Melgunova T.P. Pravo. administratsiya i sudv reformakh Ekateriny Velikoy [Law, Administration and the Court in Catherine the Great Reforms]. Saint Petersburg, Publishing house RGPU, Herzen, 2002.412 p.

20. Melnikova V.V. Tsaritsyinskiy gorodovoy magistrat $v$ kontse XVIII - XIX v. [City Magistrate of Tsaritsyn at the End of the $18^{\text {th }}-19^{\text {th }}$ Century]. Volgograd, Izd-vo VolGU, 2017. 79 p.

21. Polnoe sobranie zakonov Rossiyskoy imperii. Sobr. 1 [Complete Collection of Laws of the Russian Empire. Collection 1]. Saint Petersburg, 1830.

22. Preferansov S.A. Otrazhenie obshcherusskikh norm $i$ mestnykh osobennostey sostavleniya dokumentov $v$ deloproizvodstve Tsaritsynskogo gorodovogo magistrata: na materiale istochnikov kontsa XVIII veka [Reflection of the All-Russian Rules and Local Features of Drawing up Documents in Proceedings of the City Magistrate of Tsaritsyn (Based on the $18^{\text {th }}$ Century Sources)]. Volgograd, 2012. $167 \mathrm{p}$.

23. Protokol voevodskoy kantselyarii ot 11 marta 1784 goda [Protocol of Provincial Office of March 11, 1784]. Gosudarstvennyy arkhiv Volgogradskoy oblasti [State Archive of the Volgograd Region], F. 331, Op. 1, D. 34.

24. Protokol zasedaniya Tsaritsyinskogo gorodovogo magistrata ot 15 marta 1784 goda [Minutes of the Session of the City Magistrate of Tsaritsyn of March 15, 1784]. Gosudarstvennyy arkhiv Volgogradskoy oblasti [State Archive of the Volgograd Region], F. 233, Op. 2, D. 1.

25. Protokol zasedaniya Tsaritsyinskogo gorodovogo magistrata ot 26 marta 1846 goda [Minutes of the Session of the City Magistrate of Tsaritsyn of March 26, 1846]. Gosudarstvennyy arkhiv Volgogradskoy oblasti [State Archive of the Volgograd Region], F. 233, Op. 1, D. 158.

26. Protokol zasedaniya Tsaritsyinskogo gorodovogo magistrata ot 26 maya 1858 goda [Minutes 
of the Session of the City Magistrate of Tsaritsyn of May 26, 1858]. Gosudarstvennyy arkhiv Volgogradskoy oblasti [State Archive of the Volgograd Region]. F. 233. Op. 1. D. 347.

27. Protokol zasedaniya Tsaritsyinskogo gorodovogo magistrata ot 18 dekabrya 1858 goda [Minutes of the Session of the City Magistrate of Tsaritsyn of December 18, 1858]. Gosudarstvennyy arkhiv Volgogradskoy oblasti [State Archive of the Volgograd Region], F. 233, Op. 1, D. 348.

28. Protokol zasedaniya Tsaritsyinskogo gorodovogo magistrata ot 4 sentyabrya $1863 \mathrm{~g}$. [Minutes of the Session of the City Magistrate of Tsaritsyn of September 4, 1863]. Gosudarstvennyy arkhiv Volgogradskoy oblasti [State Archive of the Volgograd Region]. F. 233. Op. 1, D. 445.

29. Savelyev V.V. Gradostroitelnaya reforma Ekateriny II: formirovaniye priyemov «regulyarnogo» gradostroitelstva i mekhanizm ikh osushchestvleniya (po materialam Tverskogo namestnichestva) [Urban Planning Reform of Catherine II: Techniques of "Regular" Town Planning and Their Implementation (Based on the Materials of Tver Governorship)]. Saint Petersburg, 2002. 274 p.

30. Sereda N.V. Gorodovye magistraty $v$ rossiyskom zakonodatelstve XVIII veka [City Magistrates in the Russian Legislation of the $18^{\text {th }}$ Century]. Vologda, 2002, pp. 24-59.

31. Sereda N.V. Gorodovyye magistraty posledney chetverti XVIII v.: istochnikovedcheskoye issledovanie po materialam Tverskoy gubernii [City Magistrates of the Last Quarter of the $18^{\text {th }}$ Century: Source Study of the Tver Province]. Moscow, 1994. $278 \mathrm{p}$.
32. Solopova T.A. Magistraty Saratovskoy gubernii [Magistrates of the Saratov Province]. Istorik $i$ istoriografiya [The Historian and Historiography]. Saratov, Sarat. University Press, 1999, pp. 178-187.

33. Tarlovskaya V.R. Iz istorii gorodskoy reformy v Rossii kontsa XVII nachala XVIII v. [From the History of Urban Reform in Russia in the late $17^{\text {th }}$ - early $18^{\text {th }}$ Century]. Gosudarstvennyye uchrezhdeniya Rossii XVI-XVIII vv. [Government Agencies of Russia in the $16^{\text {th }}-18^{\text {th }}$ Centuries]. Moscow, 1991, pp. 98-118.

34. Ukaz Saratovskogo gubernskogo pravleniya ot 22 avgusta 1858 goda [The Decree of the Saratov Provincial Government of August 22, 1858]. Gosudarstvennyy arkhiv Volgogradskoy oblasti [State Archive of the Volgograd Region], F. 233, Op. 1, D. 234.

35. Utkin D.E. Reforma mestnogo upravleniya Ekateriny II: opyt detsentralizatsii ispolnitelnoy vlasti [The Local Administration Reform of Catherine II: Experience of Executive Power Decentralization]. Vestnik Yaroslavskogo gosudarstvennogo universiteta im. P.G. Demidova [Bulletin of the Yaroslavl State University named after P.G. Demidov], 2016, no. 2(36), pp. 15-18.

36. Khokholev D.E. Ekaterinburgskiy gorodovoy magistrat $\mathrm{v}$ sisteme upravleniya Permskogo namestnichestva (1781 - 1796 gg.) [Ekaterinburg City Magistrate in the Control System of the Perm Governorship (1781-1796 gg.)]. Problemy istorii mestnogo upravleniya Sibiri kontsa XVI-XX vekov: Materialy 4-y region. Nauch. konf. 11-12 noyab. $1999 \mathrm{~g}$. [Problems of Local Management of Siberia at the End of $16^{\text {th }}-20^{\text {th }}$ Centuries: Proceedings of the $4^{\text {th }}$ Regional Scientific Conference, November 11-12, 1999]. Novosibirsk, 1999, pp. 194-199.

\section{Information about the Authors}

Elena V. Bulyulina, Doctor of Sciences (History), Associate Professor, Department of Russian Language and Documentation, Volgograd State University, Prosp. Universitetsky, 100, 400062 Volgograd, Russian Federation, iryas@volsu.ru, bulyulina@mail.ru, http://orcid.org/0000-0001-9253-3725

Valentina V. Melnikova, Historian-Archivist, Veteran of the Archival Service, State Archive of the Volgograd Region, Kommunisticheskaya St., 30, 400131 Volgograd, Russian Federation, melhist@mail.ru, http://orcid.org/0000-0001-6370-6201

\section{Информация об авторах}

Елена Владимировна Булюлина, доктор исторических наук, доцент кафедры русского языка и документалистики, Волгоградский государственный университет, просп. Университетский, 100, 400062 г. Волгоград, Российская Федерация, iryas@volsu.ru, bulyulina@mail.ru, http:// orcid.org/0000-0001-9253-3725

Валентина Владимировна Мельникова, историк-архивист, ветеран архивной службы, Государственный архив Волгоградской области, ул. Коммунистическая, 30, 400131 г. Волгоград, Российская Федерация, melhist@mail.ru, http://orcid.org/0000-0001-6370-6201 